\title{
Evaluating the impact of early years educational reform in Wales to age seven: the potential use of the UK Millennium Cohort Study
}

\section{Chris Taylor, Heather Joshi \& Caroline Wright}

To cite this article: Chris Taylor, Heather Joshi \& Caroline Wright (2015) Evaluating the impact of early years educational reform in Wales to age seven: the potential use of the UK Millennium Cohort Study, Journal of Education Policy, 30:5, 688-712, DOI: 10.1080/02680939.2014.963164

To link to this article: http://dx.doi.org/10.1080/02680939.2014.963164

$$
\begin{aligned}
& \text { (c) } 2015 \text { The Author(s). Published by Taylor \& } \\
& \text { Francis }
\end{aligned}
$$

\section{Published online: 06 Oct 2014.}

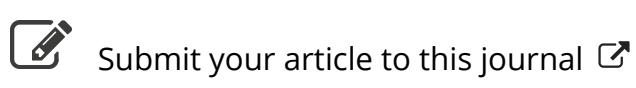

\section{Џll Article views: 779}

Q View related articles $\sqsubset$

$$
\text { View Crossmark data }
$$




\title{
Evaluating the impact of early years educational reform in Wales to age seven: the potential use of the UK Millennium Cohort Study
}

\author{
Chris Taylor $^{\mathrm{a} *}$, Heather Joshi ${ }^{\mathrm{b}}$ and Caroline Wright ${ }^{\mathrm{a}}$ \\ ${ }^{a}$ Wales Institute of Social and Economic Research, Data and Methods (WISERD), Cardiff \\ University, Cardiff, UK; ${ }^{b}$ Centre for Longitudinal Studies, Institute of Education, University \\ of London, London, UK
}

(Received 30 July 2013; accepted 4 September 2014)

\begin{abstract}
Early years education has received considerable attention in recent years, particularly as a result of longitudinal studies that demonstrate the importance of the first few years in a child's development and educational experience. In 2004, a new approach to early years education, the Foundation Phase, was introduced in Wales. This is a major flagship policy of the recently devolved Welsh Government, and marks a radical departure from the more assessment-driven competency-based approaches to early childhood education that existed prior to the Foundation Phase. Studying approximately 2000 children in Wales who are part of the UK Millennium Cohort Study (MCS), all born in 2000-2001 we investigate the potential impact of the Foundation Phase pilot on a range of key academic and well-being outcome measures. Compared with other children, those attending a Foundation Phase pilot school tended to have lower scores in a number of academic assessments at age seven and lower subjective well-being, in terms of their attitudes to learning and well-being at school. We consider these surprising, yet concerning, results in the context of the methodological limitations to this analysis and propose how the MCS can be further used to substantiate these findings.
\end{abstract}

Keywords: foundation phase; longitudinal research; achievement; well-being

\section{Introduction}

Longitudinal research and the UK birth cohort studies, in particular, have made a significant contribution to understanding the importance of the first few years of a child's life on their later educational and social outcomes (e.g. Feinstein 2003; Cunha et al. 2006; Field 2010). Such studies have also been important in helping to identify the relative influence of parental background and behaviour and early years child care and education on the educational development of children, albeit to varying degrees (Sylva et al. 2004; Ermisch 2008; Kiernan and Mensah 2011). A major consequence of this research has been the development of educational policies and initiatives to try and redress inequalities in early childhood development. In England, there has been the launch of the National Childcare Strategy in 1998, including to the establishment of Sure Start, state provision of pre-school provision from 2004, the 2006 Childcare Act and the introduction in 2008 of the Early Years Foundation Stage (EYFS) for children from birth to age five.

*Corresponding author. Email: TaylorCM@cardiff.ac.uk 
This recent attention on early years childcare and education also coincides with political devolution across the four home nations of the UK. For example, this has also led to the publication of the Early Years Framework by the Scottish Government in 2008, distinct from the EYFS by including children up to the age of eight. This Framework also draws heavily upon research that signals the importance of early years intervention. In Wales too, childcare and education in the early years was an early priority for the newly devolved Welsh Government. This led to the development of the Flying Start programme, aimed at families with children less than four years of age, living in the most deprived areas of Wales, and the Foundation Phase, a new statutory curriculum for all children aged three to seven years that applies to all maintained and funded non-maintained early years settings. ${ }^{1}$ It has been argued, particularly with the introduction of the Foundation Phase, that the early years policy in Wales has been the most innovative and distinct of all the countries of the UK (Wincott 2005, 2006). Indeed, the Foundation Phase has wideranging and ambitious aims (Maynard et al. 2013). These include raising children's standards of achievement; enhancing their positive attitudes to learning; addressing their developing needs; enabling them to benefit from educational opportunities later in their lives; and to help them become active citizens within their communities (NAfW 2003).

But not only have longitudinal research and the birth cohort studies been influential in highlighting the need for early years intervention in education and childcare, such research has increasing importance in evaluating the impact of the resulting policy interventions. For example, the Millennium Cohort Study (MCS), a birth cohort study of children born across the UK in 2000-2001, has been useful in examining, amongst other things, the quality of childcare settings (Melhuish et al. 2010), the establishment of Action for Children Children's Centres (Blewett et al. 2011), the influence of different forms of early childcare (Hansen and Hawkes 2009), the levels of attendance in early years' education on assessments in the EYFS Profile at the end of Reception class (Hopkin, Stokes, and Wilkinson 2009) and results at Key Stage 1 (George, Stokes, and Wilkinson 2012). However, what very few of these studies have been able to do is to examine the impact of a major national educational policy in early years education. This is primarily because such policies tend to be rolled out on a universal basis, thereby not allowing for a counterfactual in any analysis of outcomes. ${ }^{2}$

Not only does the introduction of the Foundation Phase in Wales provide a significant and new approach to early years education, the way it has been rolled out to schools on a phased basis also appears to lend itself well to evaluation using the MCS. The MCS birth cohort coincides at relevant ages with the pilot phase of the Foundation Phase, in which 22 primary schools (one in each local authority of Wales) implemented the new curriculum and approach whilst the remaining primary schools in Wales continued to teach the original Key Stage 1 National Curriculum. This means that the MCS includes children of the same birth cohort in Wales who either attended schools teaching Key Stage 1 (KS1) national curriculum or schools teaching the (pilot of the) new Foundation Phase, thereby potentially providing the counterfactual that is often missing in other longitudinal analyses of national educational policies. However, using the MCS in this quasi-experimental way is not straightforward and poses a number of important methodological challenges.

The aim of this paper is, therefore, to see how the MCS can be used to evaluate the effects of introducing the Foundation Phase in Wales on children's educational 
attainment and well-being. Specifically, the paper discusses the methodological challenges in using the MCS for such purposes before exploring what effects (if any) there are of attending a Foundation Phase pilot school on measures of academic attainment and well-being. We take two different measures of educational attainment at age seven (Word Reading Ability and Maths Ability assessments) and several indicators of child subjective well-being specifically developed for this survey - attitudes to learning and well-being in school. In using statistical models we are able to demonstrate the extent to which attending a Foundation Phase pilot school is associated with higher or lower levels of academic achievement or wellbeing after taking into account a range of other contributory factors, such as the home learning environment (HLE) and, critically, a child's prior educational attainment or school readiness on entry to primary school. Unexpectedly and contrary to the aims of the Foundation Phase, we find that attending a Foundation Phase pilot school was often associated with lower educational attainment and lower measures of well-being. These results are then discussed in the context of both the further potential of the MCS for educational research and the ongoing evaluation of the Foundation Phase in Wales.

\section{The Foundation Phase in Wales}

The Foundation Phase is a Welsh Government flagship policy of early years education for children aged three to seven in Wales. It appears to mark a radical departure from the more assessment-driven, competency-based approach of the previous KS1 National Curriculum, to a more experiential, play-based approach to teaching and learning, akin to early years programmes in Reggio Emilia, Te Whãriki and Sweden (Maynard et al. 2013). The Foundation Phase involves greater reliance on active learning and play, with a strong emphasis on out-of-school learning. It also provides the resources for schools to lower adult:child ratios in classes to 1:8 in Reception classes and 1:15 in Years 1 and 2 classes.

The Foundation Phase was developed following the identification of a number of shortcomings in KS1. It is considered to be a fairly radical departure from KS1 in its approach, pedagogy and curriculum. Underpinning the design of the Foundation Phase is a "developmental" approach and a constructivist but largely socio cultural pedagogy' (Maynard et al. 2013, ix). Implicit in the context and aims of the Foundation Phase is a desire to raise educational attainment, particularly for those who would have previously not met the Level 2 threshold in KS1. However, with an emphasis on 'stage not age' - referring to the developmental stage of a child rather than there being an expected level of development by a particular chronological age - it is perhaps not expected that levels of educational attainment will dramatically improve by the age of seven. Instead greater emphasis is placed on the need to enhance a child's social and emotional well-being and attitudes to learning during the first few years of compulsory education. So, for example, at the core of the Foundation Phase is the 'Personal and Social Development, Well-being and Cultural Diversity' area of learning that reflects these broader aims and ambitions. It is argued that giving these qualities greater attention in the early years of schooling will provide the basis of improved abilities and educational attainment when the children are older - possibly by the end of Key Stage 2, and certainly by the end of Key Stage 4. 
In 2004-2005, 22 primary (or infant) schools were assigned to a pilot stage of the Foundation Phase. Crucially, this pilot stage was established to help policy-makers and the curriculum authority (ACCAC at the time) to design, develop and prepare the Foundation Phase framework, curriculum and pedagogical approach that would then be introduced to all other primary schools and funded non-maintained settings across Wales a few years later. Unfortunately the pilot schools were not randomly allocated, and nor were they systematically selected (Siraj-Blatchford et al. 2007; Maynard et al. 2013). It is clear, however, that each local authority in Wales originally volunteered one or more schools, with one school from each local authority finally selected by the Welsh Government. In addition to these primary schools, 22 funded non-maintained settings were also selected to be part of the pilot phase, and again, with one setting from each local authority. However, these funded non-maintained settings are not critical to this analysis, as we are primarily interested in the effects of the Foundation Phase pilot schools on children after the age of three years. ${ }^{3}$

The Foundation Phase was then rolled out to the remaining primary schools in Wales in two further stages over the following four years. At each stage of the roll-out, including the pilot stage, the Foundation Phase was phased into schools, starting only with children in nursery and/or reception classes (i.e. with children aged three to five in the first instance). These cohorts of children, and every successive cohort of children entering the schools, then followed the Foundation Phase until the end of Year 2, when children were aged six to seven years. The staged roll-out to different groups of schools at a time and the phased introduction of the Foundation Phase into each school has meant that it was only in 2011-2012 that all children aged three to seven years were in the Foundation Phase (see Taylor et al. 2013 for further information).

Despite the potential of the staged introduction of the Foundation Phase across Wales for evaluative purposes, there are a number of limitations in evaluating its impact. First, there is a limited record as to how the pilot stage developed and was used in helping produce the official Foundation Phase curriculum and guidance materials. Second, despite the pilot stage being integral to the development of the Foundation Phase, a process evaluation of the Foundation Phase pilot stage (Siraj-Blatchford et al. 2007) found considerable variation in the 'effective' implementation of the Foundation Phase between schools (and particularly between funded non-maintained settings). Third, it is increasingly recognised that the Foundation Phase has generally not been easy to immediately implement, particularly for practitioners (Maynard et al. 2013). Fourth, routine monitoring or evaluation of the Foundation Phase has been difficult to undertake, largely because no baseline data was collected for children on entry to the Foundation Phase. And finally, comparing the end of KS1 assessments with the end of Foundation Phase assessments is not straightforward since they differ in focus and in the level of ability that they each record (Davies et al. 2013).

It is important to note, therefore, that any evaluation of the impact of the Foundation Phase is limited by the considerable variation in the degree to which the Foundation Phase has been implemented across schools. However, it is still very important to see whether the introduction of the Foundation Phase is associated with beneficial outcomes for children, even if the benefits are modest.

\section{Using the MCS to evaluate the Foundation Phase}

The discussion above begins to demonstrate some of the difficulties and challenges in evaluating the Foundation Phase. The first challenge is the lack of systematic 
on-entry assessment of children prior to starting the Foundation Phase. Several studies using the MCS have demonstrated the importance of a child's educational attainment at age three in predicting their educational attainment at age five or seven (e.g. Hansen 2010a; Dearden, Sibieta, and Sylva 2011; George, Stokes, and Wilkinson 2012; Jerrim and Vignoles 2013). Without a measure of a child's ability on entry to the Foundation Phase at age three it is always going to be difficult to distinguish the effects of the first three years of a child's life from those of the new educational programme over ages three to seven. The second challenge is the incongruity between KS1 assessments and Foundation Phase assessments. ${ }^{4}$ Without a comparable measure of achievement it is difficult to compare a child who was taught through the KS1 National Curriculum with a child taught through the Foundation Phase. The third challenge is that given the key aim of the Foundation Phase to enhance a child's well-being and attitudes to learning there are no formal mechanisms or measures in place to assess these qualities. A fourth broader challenge is the complex nature of the Foundation Phase and its wide-ranging set of activities that make an evaluation of it very difficult, particularly, in trying to identify causal relationships.

The MCS can help address these challenges in the following ways: (a) It provides the opportunity to examine outcomes at age seven on the basis of the school readiness of a child at age three, prior to commencing the Foundation Phase; (b) the same outcome measures are available to all children in the MCS, irrespective of whether they attended a Foundation Phase pilot school or not; (c) outcome measures at age seven can include assessments in educational attainment and indicators or measures of well-being; and (d) because the MCS provides a broad range of information on the background and life course of a child we are able to consider a wide number of 'controls' to try and isolate, as far as it is possible, ${ }^{5}$ the apparent effect of the Foundation Phase on a child's outcomes.

Crucially, the MCS is valuable to this analysis because the cohort of children in this longitudinal study coincided with the pilot stage of the Foundation Phase. The number of children recruited in Wales in the first sweep (MCS1) was 2798. This represents a $74 \%$ response rate out of the 3864 families in the original sampling frame in Wales (Plewis 2007). With attrition and net movement out of Wales this figure declined to 2039 by MCS4, when the children were aged seven . Of these at least 91 children attended a Foundation Phase pilot school in either MCS3 (age five in 2006) or MCS4 (age seven in 2008); 76 children attended a pilot school in both sweeps and 15 children attended a pilot school in either MCS3 or MCS4. ${ }^{6}$

However, using the MCS to evaluate the Foundation Phase and indeed other educational policies raises its own important methodological challenge. To date, the MCS has rarely been used to evaluate the impact of particular policies or interventions. Generally, it has been used to support or critique the underlying theories or content of educational policies, not the actual impact of particular policies. The main exception to this has been the use of the MCS to evaluate the impact of Sure Start in England. But here, the MCS was used to provide a cohort of 'controls', with additional data required on children who benefitted from the Sure Start programme (Melhuish et al. 2008).

In addition to the problem of using an observational study to evaluate a universal policy or one that has not been introduced randomly, there is a problem arising from the complex and clustered sample design of the MCS. Whilst the use of weighted estimates help to adjust for the 'disproportionately stratified cluster sample' (Plewis 2007, 15), they do not directly mitigate the impact of other 'naturally occurring' 
clustering of the sample. And since the MCS sample is clustered there is a very high probability that any members of the cohort receiving an intervention will also be clustered. We can see this in Table 1, which provides descriptive statistics for the sample of children used in the analysis. Children are divided into three main groups:

(1) Children who did not attend a Foundation Phase pilot school;

(2) Children who attended a Foundation Phase pilot school at either MCS3 or MCS4 (i.e. at age five or seven) but not both; and

(3) Children who attended a Foundation Phase pilot school at both MCS3 and MCS4 (i.e. at ages five and seven).

The top half of the table presents the number of children by area of advantage and disadvantage and then by local authority. The bottom half of Table 1 presents the number of children in the sample according to how many children are clustered in each school.

The clustered nature of the MCS sample means that children are initially clustered in particular local authorities, and to some extent in schools. And given the small number of schools involved in the pilot stage of the Foundation Phase it is not surprising that the number of 'active' schools in which children in the MCS attended is relatively low. ${ }^{7}$ So, for example, the MCS sample of children attended only 11 of the 22 FP pilot schools, and in 11 of the 22 local authorities. Furthermore, five of these FP pilot schools had fewer than four MCS children in them.

The obvious issue here is to what extent is the clustering of the MCS sample to particular schools (or localities) biased. Furthermore, to what extent was the original selection of schools to participate in the Foundation Phase pilot also biased. For example, any comparison of different groups of MCS children could be dependent on, say, the a priori effectiveness of particular schools. Even with the use of MCS weightings, this does not address the clustering of children into particular schools or the selection bias of schools into the Foundation Phase pilot. Possible responses to these problems include either fixed effect or random effects modelling (Bell and Jones 2013). A fixed effect model allows us to observe the estimated 'effect' on test performance of children who attended Foundation Phase pilot schools vs. children who did not attend Foundation Phase pilot schools. This assumes that there is just one 'effect' worth considering - that is between participating in the Foundation Phase pilot or not. However, it is equally possible that the effects of the Foundation Phase pilot vary between each school that participated in the Foundation Phase pilot. A random effects model is able to distinguish between a common 'effect' of the Foundation Phase pilot that is shared across schools involved in the pilot, and the 'effects' of attending each individual school. However, a random effects model, commonly referred to as a multi-level model (Goldstein 2011), is dependent on there being a relatively good number of children in each school (or number of level 1 entity at the higher level 2) and approximately more than 10 observations at either level. But, as Table 1 demonstrates, there are not always sufficient numbers of schools, and children in those schools, to meet these criteria fully. Consequently, this analysis draws upon two types of linear regression analyses where possible - simple fixed effects models and random effects models - and compares their results. In addition, a fixed effects model was estimated to allow for each school having unobserved characteristics affecting child outcomes. This had the effect of leading to a degree of 'volatility' on the estimates for each covariate, thereby appearing to 
Table 1. Sample descriptives of children at age seven (based on MCS subpopulation of Wales at MCS1).

\begin{tabular}{|c|c|c|c|c|c|c|}
\hline \multirow[b]{3}{*}{ Sample descriptives } & & & \multicolumn{4}{|c|}{ In Foundation Phase pilot school } \\
\hline & \multicolumn{2}{|c|}{$\begin{array}{l}\text { Not in Foundation } \\
\text { Phase pilot school }\end{array}$} & \multicolumn{2}{|c|}{$\begin{array}{c}\text { At either MCS3 or } \\
\text { MCS4 }\end{array}$} & \multicolumn{2}{|c|}{$\begin{array}{l}\text { At MCS3 and } \\
\text { MCS4 }\end{array}$} \\
\hline & Weighted & Actual & Weighted & Actual & Weighted & Actual \\
\hline Total child sample & 1963.9 & 1948 & 16.2 & 15 & 59.7 & 76 \\
\hline \multicolumn{7}{|c|}{ Children clustered by type of original sampled ward } \\
\hline Advantaged & 1023.9 & 622 & 5.5 & 3 & 7.1 & 4 \\
\hline Disadvantaged & 940.0 & 1326 & 10.7 & 12 & 52.6 & 72 \\
\hline \multicolumn{7}{|c|}{ Children clustered in local authorities (anonymised ID) } \\
\hline A & 311.1 & 311 & & & & \\
\hline B & 155.5 & 122 & & & 1.2 & 1 \\
\hline $\mathrm{C}$ & 69.2 & 89 & 3.7 & 4 & 10.1 & 11 \\
\hline D & 51.7 & 48 & 0.5 & 1 & 7.4 & 9 \\
\hline $\mathrm{E}$ & 13.1 & 21 & & & & \\
\hline $\mathrm{F}$ & 55.2 & 56 & 1.5 & 1 & & \\
\hline G & 38.4 & 32 & & & & \\
\hline $\mathrm{H}$ & 41.8 & 56 & 1.9 & 3 & 5.1 & 6 \\
\hline I & 221.7 & 146 & & & & \\
\hline $\mathrm{K}$ & 36.6 & 34 & & & & \\
\hline L & 46.6 & 43 & & & & \\
\hline M & 1.4 & 1 & & & & \\
\hline $\mathrm{N}$ & 71.9 & 102 & & & 7.4 & 12 \\
\hline $\mathrm{O}$ & 56.6 & 80 & & & & \\
\hline $\mathrm{P}$ & 73.6 & 68 & & & 0.5 & 1 \\
\hline Q & 180.2 & 189 & & & 2.8 & 2 \\
\hline $\mathrm{R}$ & 55.9 & 42 & & & & \\
\hline $\mathrm{S}$ & 27.2 & 34 & & & 1.8 & 3 \\
\hline $\mathrm{T}$ & 110.8 & 149 & 0.6 & 1 & 11.2 & 17 \\
\hline $\mathrm{U}$ & 67.3 & 76 & & & 0.5 & 1 \\
\hline V & 182.8 & 157 & 4.0 & 3 & 11.5 & 13 \\
\hline Z (in England) & 81.4 & 79 & 4.0 & 2 & & \\
\hline Number of schools & & 595 & 11 & & 11 & \\
\hline
\end{tabular}

Children clustered in schools (i.e. No. of children in each school (No. of schools in parentheses)

1
2
3
4
5
6
7
8
9
10
11
12
13

$$
\begin{gathered}
282(282) \\
192(96) \\
147(49) \\
92(23) \\
120(24) \\
198(33) \\
126(18) \\
120(15) \\
99(11) \\
100(10) \\
99(9) \\
108(9) \\
52(4)
\end{gathered}
$$

$3(2)$

0 (0)

$0(0)$

$0(0)$

$0(0)$

$0(0)$

$0(0)$

6 (1)

$0(0)$

$0(0)$

$0(0)$

0 (0)

$0(0)$

9 (1)

$0(0)$

$0(0)$

$0(0)$

$0(0)$

$12(1)$

$0(0)$

$0(0)$ 
Table 1. (Continued).

\begin{tabular}{|c|c|c|c|c|c|c|}
\hline \multirow[b]{3}{*}{ Sample descriptives } & & & \multicolumn{4}{|c|}{ In Foundation Phase pilot school } \\
\hline & \multicolumn{2}{|c|}{$\begin{array}{l}\text { Not in Foundation } \\
\text { Phase pilot school }\end{array}$} & \multicolumn{2}{|c|}{$\begin{array}{c}\text { At either MCS3 or } \\
\text { MCS4 }\end{array}$} & \multicolumn{2}{|c|}{$\begin{array}{l}\text { At MCS3 and } \\
\text { MCS4 }\end{array}$} \\
\hline & Weighted & Actual & Weighted & Actual & Weighted & Actual \\
\hline 14 & & $42(3)$ & & $3(1)$ & & $11(1)$ \\
\hline 15 & & $15(1)$ & & $2(1)$ & & $13(1)$ \\
\hline 16 & & $32(2)$ & & $0(0)$ & & $0(0)$ \\
\hline 17 & & $34(2)$ & & $0(0)$ & & $17(1)$ \\
\hline 18 & & 18 (1) & & $0(0)$ & & $0(0)$ \\
\hline 19 & & $38(2)$ & & $0(0)$ & & $0(0)$ \\
\hline 21 & & $21(1)$ & & $0(0)$ & & $0(0)$ \\
\hline
\end{tabular}

undermine the reliability of a hierarchical approach in this particular context. Nevertheless, the overall conclusion and direction of influence of the Foundation Phase pilot schools on children's outcomes remained the same.

Despite these limitations, the MCS still provides a unique opportunity to examine the relationship between the Foundation Phase and a number of key outcomes. The MCS is a major birth cohort study that follows children born between 2000 and 2001 across the UK. The MCS is fairly unique to previous birth cohort studies in that it includes children born at all times of the year and all sampled on the basis of where their home was when they were seven months old. It purposely includes a relatively large proportion of children living in disadvantaged areas and was also boosted in Wales to ensure the sample size was large enough for country-specific analyses. At the time of this research data were available from four sweeps of the MCS when the children were aged approximately nine months (MCS1), three years (MCS2), five years (MCS3) and seven years (MCS4). A fifth sweep of the MCS was undertaken during 2012 when the children were aged 11 years old. Information gathered by the MCS includes parental interviews, child academic and physical assessments, sibling questionnaires, a child self-completion questionnaire and a teachers' survey (Hansen 2010b).

In the analysis that follows we consider two sets of outcomes when children in Wales reached seven years of age. The first relates to the educational attainment of the children, and the second to their well-being in school and attitudes to learning. We now discuss each set of outcome measures in turn.

\section{Child educational attainment}

The first set of outcome measures we consider relates to the educational attainment of the children when they reached seven years of age. The MCS undertook two assessments of educational attainment in MCS4:

(1) Word Reading (British Ability Scales) ${ }^{8}$

(2) Maths Ability (NFER Progress in Maths, adapted)

In the following analyses we use standardised age-related scores for these assessments ( $t$-scores) (see Hansen 2010b for more information about these assessments and their scoring). ${ }^{9}$ 


\section{Measuring child well-being}

Given the nature and aims of the Foundation Phase it is also important to consider the relationship (if any) between attending a Foundation Phase pilot school and indicators of child well-being. No explicit measure of well-being is available in the MCS. However, a series of questions are asked of parents, teachers and the children themselves on a range of topics that include hobbies, friends, learning and happiness. Given our interest in outcomes at age seven we were able to utilise data from the child self-completion questionnaire used in MCS4. ${ }^{10}$ From the children's responses to this questionnaire we developed two indicators of well-being based on the following questions/items:

(1) Attitudes to learning

(a) Based on six items: How much a child likes school, reading, doing number work, science, PE and answering questions in class.

(2) Well-being in school

(a) Based on 12 items: How often a child tries to do their best at school, feels safe in playground, the teacher thinks they are clever, behaves well in class, finds the school interesting, feels unhappy at school, gets tired at school, gets fed up at school, talks to friends when should be working, get bullied by other children is horrible to other children, and feels left out by other children.

For both measures, responses to the questions were reverse-coded if necessary so that the higher the score the higher the level of well-being. These scores were then summed and standardised for each indicator of well-being to produce a continuous and normally distributed ${ }^{11}$ set of indices, positively reflecting the level of combined well-being.

\section{Modelling the impact of the Foundation Phase}

In total, then, we were interested in examining the relationship between attending a Foundation Phase pilot school and seven dependent outcomes (two measures of educational attainment and two measures of child well-being). Our 'intervention' is measured as a fixed effect according to whether a child attended a Foundation Phase pilot school at ages five and seven or not. In attempting to identify an association between the 'intervention' and the outcome measures we control for a range of other covariates relating to the children, their families, their educational development at age three and other characteristics of the schools they attended. The choice of 'controls' is based on previous analysis of child development at age seven for MCS children in Wales by Joshi, Ketende, and Parsons (2011). In the analysis that follows we control for the following four sets of fixed effects:

(1) Family and child background (mainly measured at the first survey): gender; ethnicity; season of birth; single- or two-parent households; social class; highest parental educational qualifications; mother's age at birth; number of older siblings; a measure of area disadvantage that was used in the original sampling design for the MCS and an estimate of family net income at age seven (equivalised for family size and imputed where data missing (Ketende, Joshi, and Michael 2010)). 
(2) Parenting behaviour, measured at age three: whether the child has regular bedtimes; and the HLE that includes how often a child is read to, how often they visit a library, whether they do singing, painting and drawing at home, and how often they are taught letters and number at home (see De la Rochebrochard 2012).

(3) Prior ability: two measures of educational development at age three are used to determine this: BAS Naming Vocabulary and Bracken School Readiness, from the Age 3 survey.

(4) School-level measures ${ }^{12}$ for the school each child was attending at age seven: the proportion of children in the school attended that were eligible for free school meals; the size of school attended; and how far it taught in the Welsh language.

Since the dependent outcomes are all continuous measures with normal distributions we used linear models to estimate the relative influence of each covariate on the outcomes. All the results are based on analyses using only the subpopulation of children in the MCS who were originally sampled in Wales. ${ }^{13}$

For all outcome measures we use a fixed effect model (i.e. single-level models). All the fixed effect models are undertaken using complex sample plans in SPSS that deals with clustering in the design of the sample and is weighted accordingly for (a) sample design, (b) non-response and (c) attrition (see Plewis 2007; Jones and Ketende 2010). However, for the reasons outlined earlier we also introduce random effects on these outcomes to reflect the hierarchical nature of the data: children (level 1) nested in schools (level 2), nested in local authorities (level 3). In other words, this allows us to consider the differential effectiveness of schools and local authorities when estimating the apparent effect of attending a Foundation Phase pilot school. As will be demonstrated later, in the main, the use of random effects rarely changes the findings or conclusions of the more standard general linear models using fixed effects only. However, where we find significant random effects for the dependent outcome measures, these are reported. But given the limitations noted above of this data for hierarchical linear modelling we do not attempt to privilege one set of results over another, and instead note their (in)consistency.

\section{The Foundation Phase and child educational attainment at age seven}

Table 2 identifies the association between attending a Foundation Phase pilot school and three measures of educational attainment at age seven after controlling for a range of factors (fixed effects). This shows that attending a Foundation Phase pilot school at ages five and seven was negatively associated with children's Word Reading Ability and Maths Ability test performances. In terms of Word Reading Ability scores attending a Foundation Phase pilot school appears to delay a child's word reading achievement by about one-and-a-half months on average, holding other things constant. ${ }^{14}$

Table 2 also demonstrates the importance of prior educational attainment (at age three) on educational attainment at age seven. Both the BAS Naming Vocabulary and Bracken School Readiness assessments at age three are positively associated with later child development for all academic assessments at age seven. This highlights the importance of taking into account a child's prior attainment before they entered the Foundation Phase on their later scores. 
Table 2. Analysis of the association of the Foundation Phase on age seven educational attainment using fixed effects.

\begin{tabular}{|c|c|c|c|c|c|}
\hline \multirow[t]{2}{*}{$\begin{array}{l}\text { Sample size } \\
R^{2}\left(\text { Adjusted } R^{2}\right)\end{array}$} & & \multicolumn{2}{|c|}{$\begin{array}{c}\text { Word reading }^{1} \\
1521 \\
0.284(0.275)\end{array}$} & \multicolumn{2}{|c|}{$\begin{array}{c}\text { Maths ability }^{2} \\
1667 \\
0.181(0.172)\end{array}$} \\
\hline & & Coefficient & SError & Coefficient & SError \\
\hline Intercept & & 18.10 & 3.92 & 23.49 & 3.23 \\
\hline \multirow[t]{3}{*}{ Foundation Phase Pilot } & $\begin{array}{l}\text { Not in FP pilot } \\
\text { school }\end{array}$ & & & & \\
\hline & $\begin{array}{l}\text { In FP pilot school at } \\
\text { MCS3 or MCS4 }\end{array}$ & 1.43 & 4.11 & -0.86 & 2.93 \\
\hline & $\begin{array}{l}\text { In FP pilot school at } \\
\text { MCS3 and MCS4 }\end{array}$ & $-3.12 * *$ & 1.11 & $-3.47 * *$ & 1.14 \\
\hline \multirow[t]{2}{*}{ Sex of child } & Male & & & & \\
\hline & Female & 0.90 & 0.54 & -0.65 & 0.49 \\
\hline \multirow[t]{2}{*}{ Ethnicity of child } & White & & & & \\
\hline & $\begin{array}{l}\text { Other ethnic } \\
\text { minority }\end{array}$ & -0.16 & 1.79 & -0.97 & 1.47 \\
\hline \multirow[t]{4}{*}{ Season of birth of child } & Autumn 2000 & & & & \\
\hline & Winter 2000/1 & $-1.34 *$ & 0.60 & 0.79 & 0.59 \\
\hline & Spring 2001 & $-2.10^{*}$ & 1.02 & 0.97 & 0.88 \\
\hline & Summer 2001 & $-3.80 * * *$ & 0.75 & $1.78^{*}$ & 0.69 \\
\hline \multirow[t]{2}{*}{ Household structure (MCS1) } & Two parents/carers & & & & \\
\hline & One parent/carer & -0.87 & 0.81 & -0.99 & 0.90 \\
\hline \multirow[t]{6}{*}{$\begin{array}{l}\text { Highest Social Class of parents } \\
\text { in household (MCS1) }\end{array}$} & $\begin{array}{l}\text { Professional or } \\
\text { managerial }\end{array}$ & & & & \\
\hline & Intermediate & 0.76 & 0.60 & -1.45 & 0.79 \\
\hline & $\begin{array}{l}\text { Small employer and } \\
\text { self-employed }\end{array}$ & 0.01 & 1.13 & -0.71 & 0.91 \\
\hline & $\begin{array}{l}\text { Low supervisory } \\
\text { and technical }\end{array}$ & 0.82 & 1.07 & 0.01 & 0.78 \\
\hline & $\begin{array}{l}\text { Semi-routine and } \\
\text { routine }\end{array}$ & -0.26 & 0.74 & -0.81 & 0.85 \\
\hline & $\begin{array}{l}\text { Not applicable or } \\
\text { unemployed }\end{array}$ & -2.10 & 1.53 & -1.59 & 1.51 \\
\hline \multirow{3}{*}{$\begin{array}{l}\text { Highest NVQ Level of parents } \\
\text { in household (MCS1) }\end{array}$} & None or overseas & & & & \\
\hline & NVQ Level 1-3 & 2.13 & 1.26 & 0.90 & 1.12 \\
\hline & NVQ Level 4-5 & $3.12 *$ & 0.13 & 1.42 & 1.08 \\
\hline \multirow[t]{5}{*}{ Mother's age at child's birth } & $13-20$ & & & & \\
\hline & $21-25$ & -0.23 & 1.04 & -1.00 & 1.00 \\
\hline & $26-30$ & 0.69 & 0.86 & -0.89 & 1.01 \\
\hline & $31-35$ & 1.78 & 1.06 & -0.42 & 1.14 \\
\hline & $36+$ & 1.41 & 1.28 & -1.36 & 1.17 \\
\hline \multirow{4}{*}{$\begin{array}{l}\text { No. of child's older siblings } \\
\text { (MCS1) }\end{array}$} & 0 & & & & \\
\hline & 1 & -0.89 & 0.54 & 0.13 & 0.73 \\
\hline & 2 & $-2.02 *$ & 0.80 & -0.20 & 1.04 \\
\hline & $3+$ & -1.38 & 1.17 & -0.63 & 1.13 \\
\hline
\end{tabular}


Table 2. (Continued).

\begin{tabular}{|c|c|c|c|c|c|}
\hline \multirow{2}{*}{\multicolumn{2}{|c|}{$\begin{array}{l}\text { Sample size } \\
R^{2}\left(\text { Adjusted } R^{2}\right)\end{array}$}} & \multicolumn{2}{|c|}{$\begin{array}{c}\text { Word reading }^{1} \\
1521 \\
0.284(0.275)\end{array}$} & \multicolumn{2}{|c|}{$\begin{array}{c}\text { Maths ability }^{2} \\
1667 \\
0.181(0.172)\end{array}$} \\
\hline & & Coefficient & SError & Coefficient & SError \\
\hline Area at first survey & $\begin{array}{l}\text { Advantaged } \\
\text { Disadvantaged }\end{array}$ & -0.13 & 0.99 & -0.73 & 0.92 \\
\hline $\begin{array}{l}\text { Weekly net family income } \\
\left(*_{£ 100)(\text { MCS4) }}\right.\end{array}$ & 0.13 & 0.07 & 0.09 & 0.09 & \\
\hline $\begin{array}{l}\text { Regular bedtimes of child } \\
\text { (MCS2) }\end{array}$ & $\begin{array}{l}\text { Never, sometimes } \\
\text { Usually, always }\end{array}$ & $-1.87^{* *}$ & 0.67 & $-1.72 * *$ & 0.63 \\
\hline $\begin{array}{l}\text { Home Learning Environment } \\
\text { (MCS2) }\end{array}$ & $\begin{array}{l}\text { Well below average } \\
\text { HLE } \\
\text { Below average HLE } \\
\text { About average HLE } \\
\text { Above average HLE } \\
\text { Well above average } \\
\text { HLE }\end{array}$ & $\begin{array}{r}-0.06 \\
-1.31 \\
0.52 \\
0.29\end{array}$ & $\begin{array}{l}0.91 \\
0.72\end{array}$ & $\begin{array}{l}0.29 \\
0.06\end{array}$ & $\begin{array}{l}0.81 \\
0.65\end{array}$ \\
\hline $\begin{array}{l}\text { BAS Naming Vocabulary ( } t \text {-scor } \\
\text { Bracken School Readiness Com } \\
\text { (MCS2) }\end{array}$ & $\begin{array}{l}\text { es) (MCS2) } \\
\text { posite Standard Score }\end{array}$ & $\begin{array}{l}0.09^{* *} \\
0.19^{* * *}\end{array}$ & $\begin{array}{l}0.04 \\
0.03\end{array}$ & $\begin{array}{l}0.17 * * * \\
0.12 * * *\end{array}$ & $\begin{array}{l}0.03 \\
0.01\end{array}$ \\
\hline $\begin{array}{l}\text { Intake composition of school } \\
\text { child attends (MCS4) } \\
\text { (\%FSM) }\end{array}$ & $\begin{array}{l}\text { Q1 Lowest } \\
\text { Q2 } \\
\text { Q3 } \\
\text { Q4 } \\
\text { Q5 Highest }\end{array}$ & $\begin{array}{l}-1.66 \\
-0.31 \\
-1.065 \\
-2.21\end{array}$ & $\begin{array}{l}1.07 \\
1.20 \\
1.15 \\
1.12\end{array}$ & $\begin{array}{r}-0.64 \\
0.53 \\
1.01 \\
0.42\end{array}$ & $\begin{array}{l}1.04 \\
0.53 \\
1.28 \\
1.08\end{array}$ \\
\hline $\begin{array}{l}\text { Intake size of school child } \\
\text { attends (MCS4) }\end{array}$ & $\begin{array}{l}\text { Q1 Smallest } \\
\text { Q2 } \\
\text { Q3 } \\
\text { Q4 } \\
\text { Q5 Largest }\end{array}$ & $\begin{array}{c}0.12 \\
-0.047 \\
1.06 \\
1.34\end{array}$ & $\begin{array}{l}1.56 \\
1.25 \\
1.47 \\
1.54\end{array}$ & $\begin{array}{l}0.97 \\
2.98 \\
1.82 \\
0.60\end{array}$ & $\begin{array}{l}2.14 \\
1.77 \\
1.82 \\
1.93\end{array}$ \\
\hline $\begin{array}{l}\text { Welsh language in school child } \\
\text { attends (MCS4) }\end{array}$ & $\begin{array}{l}\text { England school } \\
\text { Welsh is sole/main } \\
\text { medium of instrn. } \\
\text { Welsh is used in } \\
\text { part of the } \\
\text { curriculum } \\
\text { Welsh is taught as } \\
\text { 2nd language only }\end{array}$ & $\begin{array}{l}3.50^{*} \\
-3.04 * * * \\
-0.25\end{array}$ & $\begin{array}{l}1.57 \\
0.73 \\
1.57\end{array}$ & $\begin{array}{l}-2.65 \\
-1.85^{*} \\
-1.33\end{array}$ & $\begin{array}{l}1.34 \\
0.85 \\
\\
1.35\end{array}$ \\
\hline
\end{tabular}

${ }^{*} p<0.05 ; * * p<0.01 ; * * * p<0.001$.

${ }^{1}$ Word Reading Ability scores at MCS4 (Age-adjusted $t$-score). The effect size (Cohens' $d$ ) of attending a Foundation Phase pilot school at MCS3 and MCS4 (compared to not attending a Foundation Phase pilot school) in this assessment is -0.31 , and would therefore be considered a small negative effect.

${ }^{2}$ Maths Ability scores at MCS4 (Age-adjusted $t$-score). The effect size (Cohens' $d$ ) of attending a Foundation Phase pilot school at MCS3 and MCS4 (compared to not attending a Foundation Phase pilot school) in this assessment is -0.34 , and would therefore be considered a small negative effect. 
Other significant factors associated with Word Reading Ability test performance at age seven include gender (girls are on average just half a month ahead of boys), season of birth (being amongst the youngest children in the academic year is the equivalent of being two months behind in ability than the oldest children in the same academic year), having non-working parents (these children appear to be just over one month behind in their word reading achievement than children with parents in professional occupations), having older siblings (children with two or more older siblings are about one month behind in ability than children with no older siblings), and regular bedtimes (children who never or only sometimes have regular bedtimes appear to also be about one month behind in ability than those who usually or always have regular bedtimes).

In terms of Maths Ability test performance at age seven, we find again the importance of prior scores at age three and the positive association of having regular bedtimes. But otherwise very few of the other characteristics were significantly associated with performance in the maths assessment.

Finally, apart from the presence of Foundation Phase pilot schools we find little association between the school-level factors included in the model and any of the measures of educational attainment at age seven. The main exception to this is the language of instruction of the school the children attended. Children attending schools where Welsh is the sole or main medium of instruction had on average lower levels of Word Reading Ability scores and Maths Ability scores than equivalent children attending English medium schools (i.e. where Welsh is taught as a second language only). It is worth restating at this point that only children who undertook the Word Reading Ability assessments in English are included in the first model in Table 2). So, it may not be that surprising that given their main language of education is Welsh that they generally have lower levels of English Word Reading Ability attainment. But what is notable, then, is that they also generally had lower Maths Ability scores, irrespective of whether they undertook the maths assessment in English or its translation into Welsh. However, further inspection of the MCS reveals that many children from Welsh speaking families and who attended Welsh medium schools chose to do all the assessments in the medium of English. Hence, some of the differences in educational attainment may in part be due to their more limited English literacy skills. The role of language in determining academic achievement clearly warrants further analysis and will be the basis of future study.

The introduction of random effects to the models (Table 3) was also significantly associated with children's scores in Word Reading Ability and Maths Ability, both at the level of the school they attended and the local authority the school was in, but even more strongly at the level of the child. This highlights the importance of controlling for differences in the apparent effectiveness of schools and local authorities when examining the results of these two academic assessments. Crucially, however, the inclusion of these random effects does not significantly alter the significant negative association of attending a Foundation Phase pilot school at age three and five on these scores. The estimated effect of this on Word Reading Ability scores is actually greater with the introduction of random effects. And further investigation of these results shows that whether a child attended a Foundation Phase pilot school or not does appear to reduce the unexplained variance at the school level. The introduction of random effects also increases the significant effects of a number of control variables; most notably, gender, highest social class of parents, household income, highest educational qualifications of either parent, mother's age at birth and HLE. 
Table 3. Analysis of the association of the Foundation Phase on Word Reading Ability and Maths Ability at age seven using random effects.

\begin{tabular}{|c|c|c|c|c|c|}
\hline \multirow{2}{*}{$\begin{array}{l}\text { Sample size } \\
-2 * \text { loglikelihood } \\
\text { Fixed Part }\end{array}$} & & \multicolumn{2}{|c|}{$\begin{array}{c}\text { Word reading }^{1} \\
1516 \\
10,905\end{array}$} & \multicolumn{2}{|c|}{$\begin{array}{c}\text { Maths ability }^{2} \\
1662 \\
11,917\end{array}$} \\
\hline & & Coefficient & SError & Coefficient & SError \\
\hline Intercept & & 20.30 & 2.83 & 27.11 & 2.71 \\
\hline \multirow[t]{3}{*}{ Foundation Phase Pilot } & $\begin{array}{l}\text { Not in FP pilot } \\
\text { school }\end{array}$ & & & & \\
\hline & $\begin{array}{l}\text { In FP pilot school at } \\
\text { MCS3 or MCS4 }\end{array}$ & 1.47 & 2.65 & 0.50 & 2.53 \\
\hline & $\begin{array}{l}\text { In FP pilot school at } \\
\text { MCS3 and MCS4 }\end{array}$ & $-3.30^{* *}$ & 1.48 & $-3.11^{* *}$ & 1.45 \\
\hline \multirow[t]{2}{*}{ Sex of child } & Male & & & & \\
\hline & Female & $1.08^{* *}$ & 0.47 & $-0.99 * *$ & 0.44 \\
\hline \multirow[t]{2}{*}{ Ethnicity of child } & White & & & & \\
\hline & Other ethnic minority & -1.04 & 1.45 & -1.00 & 1.41 \\
\hline \multirow[t]{4}{*}{ Season of birth of child } & Autumn 2000 & & & & \\
\hline & Winter $2000 / 1$ & $-1.44 * *$ & 0.64 & 0.95 & 0.60 \\
\hline & Spring 2001 & $-1.33 * *$ & 0.66 & $1.41 * *$ & 0.62 \\
\hline & Summer 2001 & $-3.40 * * *$ & 0.65 & $2.01 * * *$ & 0.61 \\
\hline \multirow[t]{2}{*}{ Household structure (MCS1) } & Two parents/carers & & & & \\
\hline & One parent/carer & -0.95 & 0.74 & $-1.21^{*}$ & 0.70 \\
\hline \multirow{6}{*}{$\begin{array}{l}\text { Highest Social Class of } \\
\text { parents in household } \\
\text { (MCS1) }\end{array}$} & $\begin{array}{l}\text { Professional or } \\
\text { managerial }\end{array}$ & & & & \\
\hline & Intermediate & 0.70 & 0.79 & -0.41 & 0.73 \\
\hline & $\begin{array}{l}\text { Small employer and } \\
\text { self-employed }\end{array}$ & 1.04 & 1.05 & 0.27 & 1.01 \\
\hline & $\begin{array}{l}\text { Low supervisory and } \\
\text { technical }\end{array}$ & 0.82 & 0.86 & 0.21 & 0.81 \\
\hline & $\begin{array}{l}\text { Semi-routine and } \\
\text { routine }\end{array}$ & -0.45 & 0.78 & -0.92 & 0.73 \\
\hline & $\begin{array}{l}\text { Not applicable or } \\
\text { unemployed }\end{array}$ & $-2.65^{* *}$ & 1.32 & $-2.38^{*}$ & 1.27 \\
\hline \multirow{3}{*}{$\begin{array}{l}\text { Highest NVQ Level of } \\
\text { parents in household } \\
\text { (MCS1) }\end{array}$} & None or overseas & & & & \\
\hline & NVQ Level 1-3 & $2.45^{* * *}$ & 0.92 & 0.80 & 0.88 \\
\hline & NVQ Level 4-5 & $3.62 * * *$ & 1.06 & 1.53 & 1.01 \\
\hline \multirow[t]{4}{*}{ Mother's age at child's birth } & $13-20$ & & & & \\
\hline & $21-25$ & -0.64 & 0.87 & -1.13 & 0.82 \\
\hline & $\begin{array}{l}26-30 \\
31-35\end{array}$ & $\begin{array}{l}0.35 \\
0.96\end{array}$ & $\begin{array}{l}0.89 \\
0.96\end{array}$ & $\begin{array}{l}-0.94 \\
-1.05\end{array}$ & $\begin{array}{l}0.84 \\
0.91\end{array}$ \\
\hline & $36+$ & -0.32 & 1.10 & $-2.17 * *$ & 1.03 \\
\hline \multirow{4}{*}{$\begin{array}{l}\text { No. of child's older siblings } \\
\text { (MCS1) }\end{array}$} & 0 & & & & \\
\hline & 1 & -0.37 & 0.55 & 0.64 & 0.52 \\
\hline & 2 & $-1.76 * * *$ & 0.75 & -0.34 & 0.70 \\
\hline & $3+$ & -0.77 & 1.08 & -0.41 & 1.02 \\
\hline
\end{tabular}


Table 3. (Continued).

\begin{tabular}{|c|c|c|c|c|c|}
\hline \multirow{2}{*}{$\begin{array}{l}\text { Sample size } \\
-2 * \text { loglikelihood } \\
\text { Fixed Part }\end{array}$} & & \multicolumn{2}{|c|}{$\begin{array}{c}\text { Word reading }^{1} \\
1516 \\
10,905\end{array}$} & \multicolumn{2}{|c|}{$\begin{array}{c}\text { Maths ability }^{2} \\
1662 \\
11,917\end{array}$} \\
\hline & & Coefficient & SError & Coefficient & SError \\
\hline \multirow[t]{2}{*}{ Area at first survey } & Advantaged & & & & \\
\hline & Disadvantaged & -0.16 & 0.65 & -0.33 & 0.63 \\
\hline \multicolumn{2}{|l|}{$\begin{array}{l}\text { Weekly net family income } \\
\left({ }^{*} 1100\right)(\mathrm{MCS} 4)\end{array}$} & $0.17 *$ & 0.09 & 0.10 & 0.08 \\
\hline $\begin{array}{l}\text { Regular bedtimes of child } \\
\text { (MCS2) }\end{array}$ & $\begin{array}{l}\text { Never, sometimes } \\
\text { Usually, always }\end{array}$ & $-0.96^{*}$ & 0.58 & $-1.52 * * *$ & 0.55 \\
\hline \multirow[t]{4}{*}{$\begin{array}{l}\text { Home Learning Environment } \\
\text { (MCS2) }\end{array}$} & $\begin{array}{l}\text { Well below average } \\
\text { HLE }\end{array}$ & 0.08 & 0.73 & 0.32 & 0.69 \\
\hline & $\begin{array}{l}\text { Below average HLE } \\
\text { About average HLE }\end{array}$ & $-1.47 * *$ & 0.69 & -0.25 & 0.65 \\
\hline & Above average HLE & 0.80 & 0.77 & 0.76 & 0.72 \\
\hline & $\begin{array}{l}\text { Well above average } \\
\text { HLE }\end{array}$ & -0.12 & 0.68 & 0.24 & 0.64 \\
\hline \multirow{2}{*}{\multicolumn{2}{|c|}{$\begin{array}{l}\text { BAS Naming Vocabulary ( } t \text {-scores) (MCS2) } \\
\text { Bracken School Readiness Composite Standard Score } \\
\text { (MCS2) }\end{array}$}} & $0.11^{* * *}$ & 0.03 & $0.15^{* * *}$ & 0.03 \\
\hline & & $0.19 * * *$ & 0.02 & $0.12 * * *$ & 0.02 \\
\hline \multirow{4}{*}{$\begin{array}{l}\text { Intake composition of school } \\
\text { child attends (MCS4) } \\
(\% \text { FSM) }\end{array}$} & Q1 Lowest & & & & \\
\hline & & $\begin{array}{l}-1.15 \\
-0.42\end{array}$ & $\begin{array}{l}0.81 \\
0.86\end{array}$ & $\begin{array}{l}-0.21 \\
-0.05\end{array}$ & $\begin{array}{l}0.86 \\
0.85\end{array}$ \\
\hline & & -0.99 & 0.96 & $1.64 *$ & 0.96 \\
\hline & Q5 Highest & $-1.71^{*}$ & 0.97 & 1.44 & 0.97 \\
\hline \multirow{5}{*}{$\begin{array}{l}\text { Intake size of school child } \\
\text { attends (MCS4) }\end{array}$} & Q1 Smallest & & & & \\
\hline & & 0.80 & 1.65 & 1.29 & 1.62 \\
\hline & Q3 & 0.37 & 1.56 & 2.47 & 1.54 \\
\hline & Q4 & 1.07 & 1.54 & 2.44 & 1.52 \\
\hline & Q5 Largest & 1.03 & 1.56 & 1.50 & 1.53 \\
\hline \multirow{3}{*}{$\begin{array}{l}\text { Welsh language of school } \\
\text { child attends (MCS4) }\end{array}$} & England school & 5.04 & 3.66 & -1.51 & 3.72 \\
\hline & $\begin{array}{l}\text { Welsh is sole/main } \\
\text { medium of instrn. }\end{array}$ & $-1.61^{*}$ & 0.84 & -0.92 & 0.74 \\
\hline & $\begin{array}{l}\text { Welsh is used in part } \\
\text { of the curriculum } \\
\text { Welsh is taught as } \\
\text { 2nd language only }\end{array}$ & -0.11 & 1.62 & -0.83 & 1.63 \\
\hline \multicolumn{6}{|l|}{ Random Part } \\
\hline \multicolumn{2}{|l|}{ Child } & $73.36^{* * *}$ & 2.98 & $69.84 * * *$ & 2.72 \\
\hline \multicolumn{2}{|l|}{ School } & $3.56^{* *}$ & 1.68 & $5.77 * * *$ & 1.76 \\
\hline \multicolumn{2}{|l|}{ Local authority } & $3.74 * *$ & 1.68 & $5.19 * * *$ & 2.14 \\
\hline
\end{tabular}

${ }^{*} p<0.05 ; * * p<0.01 ; * * * p<0.001$.

${ }^{1}$ Word Reading Ability scores at MCS4 (Age-adjusted $t$-score).

${ }^{2}$ Maths Ability scores at MCS4 (Age-adjusted $t$-score). 
By not accounting for the higher level variance at the school and local authority level, the results from the first model (Table 2) underestimate the size and significance of their effects. It is also perhaps interesting to note that in the random effects model social class, household income and parental education all have a significant association with the educational scores, even when they are all included in the same model. This reinforces arguments made by Bukodi and Goldthorpe (2013) that these factors, which are often used interchangeably, or as proxies for one another, have 'independent and distinctive effects on educational attainment' (1024).

\section{The Foundation Phase and child well-being}

Finding that children in Foundation Phase pilot schools were associated with marginally lower word reading and maths achievement may not be all that surprising given the nature of the Foundation Phase pedagogy and philosophy. The focus on developmentallyappropriate practice vs. age-appropriate standards may coincide with some form of delayed acquisition of literacy and numeracy skills at the age of seven. However, the Foundation Phase is designed to foster a greater appreciation of school and learning in order to provide stronger foundations for learning at a later age. Consequently, the analysis now shifts to look at the relationship between attending a Foundation Phase pilot school and our measures of child well-being.

The first thing to note is how difficult it is to predict self-reported well-being (as measured by the two indices considered here) as indicated by the low adjusted $R^{2}$ results for each model in Table 4. However, there are some useful findings from this, particularly in the context of examining the possible impact of attending a Foundation Phase pilot school.

Table 4 demonstrates that attending a Foundation Phase pilot school (at age five and seven) is negatively associated with the children's well-being at school. It is also negatively associated with attitudes to learning but not at the $95 \%$ confidence interval. It is also useful to note that these two measures of well-being are related to education, as demonstrated by their positive association with one measure of educational attainment at age three (represented here by their BAS Naming Vocabulary scores).

It would also seem that girls are significantly more likely to report positive attitudes to learning and well-being at school than boys, all other things being equal. Household levels of income appear to be only significantly related to attitudes to learning - the greater the income the more positive attitudes towards learning. Conversely, having older siblings is commonly associated with more negative attitudes towards learning.

Given these measures of child well-being are not adjusted for the exact age at interview, unlike the academic assessments employed earlier, it is interesting to note that there is no clear and consistent relationship between season of birth and levels of well-being. Furthermore, in relation to social class there is very little association, other things equal, between different occupational groupings and children's levels of school well-being or attitudes to learning. However, children whose parents had higher educational qualifications were associated with higher levels of well-being at school.

A final point to note here is that children attending schools where Welsh is used in part of the curriculum (i.e. officially bilingual schools) tend to have, on average, lower levels of well-being at school. Given such schools are likely to admit both 
Table 4. Analysis of the association of the Foundation Phase on subjective attitudes to learning and well-being at school at age seven using fixed effects.

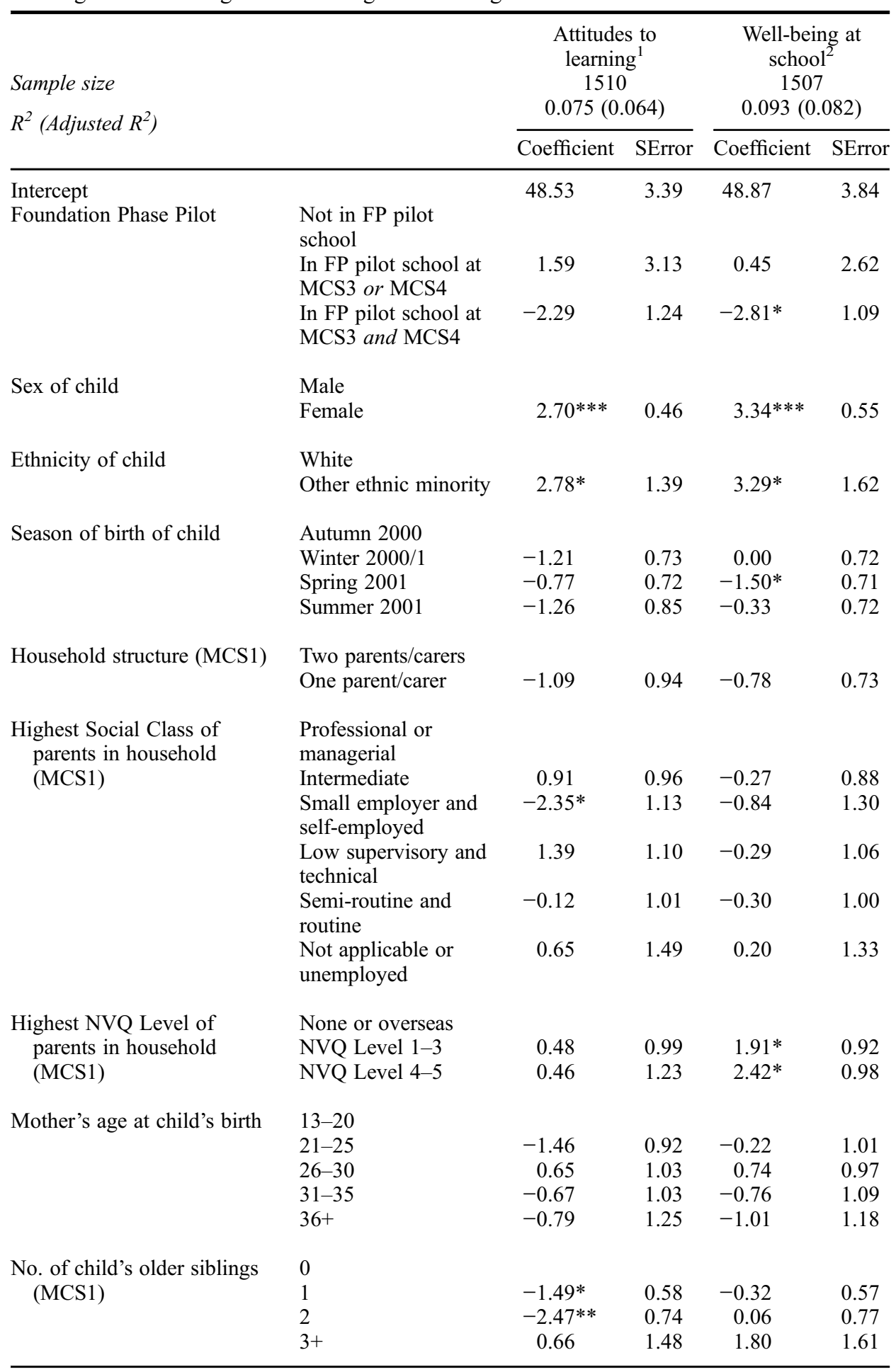


Table 4. (Continued).

\begin{tabular}{|c|c|c|c|c|c|}
\hline \multirow[t]{2}{*}{$\begin{array}{l}\text { Sample size } \\
\left.R^{2} \text { (Adjusted } R^{2}\right)\end{array}$} & & \multicolumn{2}{|c|}{$\begin{array}{c}\text { Attitudes to } \\
\text { learning }{ }^{1} \\
1510 \\
0.075(0.064)\end{array}$} & \multicolumn{2}{|c|}{$\begin{array}{c}\text { Well-being at } \\
\text { school }^{2} \\
1507 \\
0.093(0.082)\end{array}$} \\
\hline & & Coefficient & SError & Coefficient & SError \\
\hline Area at first survey & $\begin{array}{l}\text { Advantaged } \\
\text { Disadvantaged }\end{array}$ & 0.80 & 0.48 & -0.14 & 0.67 \\
\hline Weekly net family income $\left(*_{f}\right.$ & .00) (MCS4) & $0.20 *$ & 0.10 & 0.21 & 0.11 \\
\hline $\begin{array}{l}\text { Regular bedtimes of child } \\
\text { (MCS2) }\end{array}$ & $\begin{array}{l}\text { Never, sometimes } \\
\text { Usually, always }\end{array}$ & -0.12 & 0.56 & 0.38 & 0.72 \\
\hline $\begin{array}{l}\text { Home Learning Environment } \\
\text { (MCS2) }\end{array}$ & $\begin{array}{l}\text { Well below average } \\
\text { HLE } \\
\text { Below average HLE } \\
\text { About average HLE } \\
\text { Above average HLE } \\
\text { Well above average } \\
\text { HLE }\end{array}$ & $\begin{array}{r}-0.17 \\
-0.92 \\
-0.67 \\
0.20\end{array}$ & $\begin{array}{l}0.74 \\
0.72\end{array}$ & $\begin{array}{l}-2.04 * \\
-1.97 * \\
-0.79 \\
-1.15\end{array}$ & $\begin{array}{l}0.91 \\
0.80\end{array}$ \\
\hline $\begin{array}{l}\text { BAS Naming Vocabulary }(t-\mathrm{sc} \\
\text { Bracken School Readiness Co } \\
\text { (MCS2) }\end{array}$ & $\begin{array}{l}\text { res) (MCS2) } \\
\text { nposite Standard Score }\end{array}$ & $\begin{array}{l}0.07^{*} \\
-0.00\end{array}$ & $\begin{array}{l}0.03 \\
0.02\end{array}$ & $\begin{array}{r}0.07 \\
-0.01\end{array}$ & $\begin{array}{l}0.04 \\
0.02\end{array}$ \\
\hline $\begin{array}{l}\text { Intake composition of school } \\
\text { child attends (MCS4) } \\
\text { (\%FSM) }\end{array}$ & $\begin{array}{l}\text { Q1 Lowest } \\
\text { Q2 } \\
\text { Q3 } \\
\text { Q4 } \\
\text { Q5 Highest }\end{array}$ & $\begin{array}{r}-1.18 \\
-0.31 \\
1.13 \\
1.03\end{array}$ & $\begin{array}{l}0.66 \\
0.84 \\
0.82 \\
0.92\end{array}$ & $\begin{array}{l}1.97 * \\
1.66 \\
1.82 \\
1.70\end{array}$ & $\begin{array}{l}0.90 \\
0.88 \\
1.23 \\
1.04\end{array}$ \\
\hline $\begin{array}{l}\text { Intake size of school child } \\
\text { attends (MCS4) }\end{array}$ & $\begin{array}{l}\text { Q1 Smallest } \\
\text { Q2 } \\
\text { Q3 } \\
\text { Q4 } \\
\text { Q5 Largest }\end{array}$ & $\begin{array}{l}1.81 \\
2.12 \\
1.09 \\
0.98\end{array}$ & $\begin{array}{l}1.58 \\
1.25 \\
1.24 \\
1.26\end{array}$ & $\begin{array}{l}1.78 \\
3.89 * \\
3.71 \\
3.26\end{array}$ & $\begin{array}{l}1.74 \\
1.93 \\
1.89 \\
1.89\end{array}$ \\
\hline $\begin{array}{l}\text { Welsh language school child } \\
\text { attends (MCS4) }\end{array}$ & $\begin{array}{l}\text { England school } \\
\text { Welsh is sole/main } \\
\text { medium of instrn. } \\
\text { Welsh is used in part } \\
\text { of the curriculum } \\
\text { Welsh is taught as } \\
\text { 2nd language only }\end{array}$ & $\begin{array}{l}4.00 \\
0.91 \\
\\
0.97\end{array}$ & $\begin{array}{l}2.37 \\
0.62\end{array}$ & $\begin{array}{c}4.64 \\
0.44 \\
-3.20^{* *}\end{array}$ & $\begin{array}{l}3.40 \\
0.50\end{array}$ \\
\hline
\end{tabular}

$* p<0.05 ; * * p<0.01 ; * * * p<0.001$.

${ }^{1}$ Attitudes to Learning composite scores (standardised) at MCS4. The effect size (Cohens' $d$ ) of attending a Foundation Phase pilot school at MCS3 and MCS4 (compared to not attending a Foundation Phase pilot school) in this assessment is -0.23 , and would therefore be considered a small negative effect.

${ }^{2}$ Well-being at School composite scores (standardised) at MCS4. The effect size (Cohens' $d$ ) of attending a Foundation Phase pilot school at MCS3 and MCS4 (compared to not attending a Foundation Phase pilot school) in this assessment is -0.28 , and would therefore be considered a small negative effect. 
children whose home language is Welsh or English, this may suggest that the dual language nature of the schools could be at the detriment to child well-being in schools. Again, the relationship between language and child well-being is worthy of further investigation.

Unlike the measures of academic achievement reported above we find no significant random effects associated with either of the two measures of subjective wellbeing at the level of the school or the local authority, suggesting that schools (and local authorities) generally have a limited role in determining levels of well-being at school and attitudes to learning. Consequently, it is not surprising to find that the estimated effects of attending a Foundation Phase pilot school remains relatively unchanged in the random effects models (and hence the results of the random effect models are not presented here).

\section{Conclusions}

In this paper, we have explored the potential contribution of the MCS to evaluating the Foundation Phase in Wales. The use of a longitudinal study, such as the MCS, clearly addresses a number of common challenges found when relying on the use of existing administrative and educational data-sets for evaluating a major educational programme. We have also demonstrated that even with a relatively small number of cases, in this case the number of MCS cohort members who attended Foundation Phase pilot schools, considerable insights can still be made.

After substantial exploration we reach the counter-intuitive but robust finding that attending a Foundation Phase pilot school was associated with lower levels of educational attainment and lower levels of child well-being. Children attending a Foundation Phase pilot school at both age five (Reception class) and age seven (Year 2 class) had, on average, lower Word Reading Ability and Maths Ability assessment scores at age seven than similar children who did not attend a Foundation Phase pilot school at any time. However, it may suggest that, in the pilot schools at least, the Foundation Phase shifted attention away from the development of literacy and mathematical skills, in particular, to other aspects of learning. Indeed, the 'developmentally appropriate' approach of the Foundation Phase might suggest that there would be some 'status quo' (i.e. no change), or possibly even downturn, in the acquisition of literacy and numeracy abilities by the end of this phase in a child's education when compared with the previous Key Stage 1 National Curriculum.

However, the underlying intention that this new approach may encourage children to engage with learning in a more positive way and to develop their attitudes to learning and well-being in school may also be over-optimistic. The analysis presented here demonstrates that children attending a Foundation Phase pilot school throughout their early primary years were significantly more likely to report lower levels of well-being at school and had, on average, less positive dispositions towards learning. This is puzzling and counter-intuitive to the supposed research evidence that early years education programmes, such as the Foundation Phase, are based on.

Of course, despite the strengths of this approach to evaluating the Foundation Phase in Wales there are a number of caveats and limitations to this analysis that have been rehearsed throughout the paper. But two main issues need to be considered again here. The first issue relates to the pilot stage and selection of schools to participate in the pilot stage of the Foundation Phase. For example, if these pilot schools represented the most 'underperforming' primary schools in Wales we may expect to see 
children who attend these to have lower educational attainment and measures of wellbeing. Similarly, the pilot stage (and pilot schools) of the Foundation Phase could be regarded as 'experimental' and not necessarily an accurate reflection of the final rollout of the Foundation Phase in 2008/2009. However, the results of using random effects models are remarkably consistent throughout. Nevertheless, there may not have been an appropriate amount of guidance or training given to staff in these pilot schools in the first few years of implementation in order for them to fully implement the principles and approach of the new programme successfully. The fact that schools in the Foundation Phase pilot were exempted from the MCS teacher survey may indicate that participating in the new venture was already burdensome to teachers. Consequently, the extent to which we would expect to see comparable results in schools that implemented the Foundation Phase at a later date, i.e. whether these results are generalisable to the whole of the Foundation Phase, is questionable. It also highlights the need to design pilot interventions more appropriately, so that they are either selected randomly or using criteria based on prior data.

The second main issue relates to what age children should be in order to fully assess the impact of the new Foundation Phase programme. It may be the case that it is not appropriate to judge the merits (or otherwise) of the Foundation Phase when children are aged seven, on either their educational attainment or their well-being. Indeed, the Foundation Phase was introduced in order to ensure higher levels of achievement and engagement as children grow up and leave school. The question is, then, how long to wait until such a judgement can be made. Is it just 'too early to tell'?

Something we hope will help clarify and resolve both of these two issues will be to see how the children in the MCS continue to develop, academically, socially and emotionally, as they grow up. The fifth sweep of the MCS has recently been completed when the children were aged 11-12 years, and the results from this should show whether there has been some more medium-term benefit of the Foundation Phase. But, it is also realistic to expect that further analysis may confirm the initial findings presented here. In which case there may be some very difficult questions to be asked in the design of the Foundation Phase in Wales and more broadly the suitability of 'developmentally appropriate' approaches to learning and pedagogy in similar contexts.

\section{Acknowledgements}

We are also grateful for the support of the Centre for Longitudinal Studies at the Institute of Education, University of London for the use of these data and to the UK Data Archive and Economic and Social Data Service for making them available (University of London, Institute of Education, Centre for Longitudinal Studies 2012a, 2012b, 2012c, 2012d). We are particularly grateful for the help of Jon Johnson in providing the linked school-level data. We also acknowledge the funding of the data collection by Economic and Social Research Council and the consortium of government departments led by the Office for National Statistics (and including the Welsh Government). We are indebted to the families who have voluntarily provided their information to the study and are grateful for the constructive comments of the anonymous referees. However, none of these organisations or individuals bears any responsibility for the analysis or interpretation of these data.

\section{Funding}

This work was supported by the Economic and Social Research Council [grant number RES-070-27-0070]. 


\section{Notes}

1. At the time of writing, parents in Wales are entitled to 10 hours of free nursery provision for three- and four-year-olds prior to their children reaching compulsory school age. In some local authorities of Wales this free entitlement can be accessed from nursery settings, child minders and other childcare providers in the private, non-maintained, sector. Such settings have to be accredited educational providers and have to deliver the Foundation Phase. They are referred to as the 'funded non-maintained sector'.

2. With political devolution there has been significant divergence in the education systems and policies of England, Northern Ireland, Scotland and Wales since the beginning of the twenty-first Century. It should be acknowledged, therefore, that comparative analyses across the different countries of the UK provide the opportunity for 'natural experiments' in educational research that provide for some form of counterfactual in their analyses (Raffe et al. 1999; Taylor, Rees, and Davies 2013). However, this paper does not consider the potential for using longitudinal studies, such as the MCS, in this way, as it is solely concerned with evaluating educational policy within a single country of the UK that does not require any comparison with other countries and their educational policies.

3. It could be argued that this analysis, then, does not examine the whole Foundation Phase years and programme. However, policy analysis of the Foundation Phase suggests that there has been minimal change in the education of three- to four-year-olds - indeed, the curriculum of the Foundation Phase is an extension of the previous non-compulsory curriculum (Maynard et al. 2013).

4. Although the assessments are produced at the same time (at the end of Year 2) the assessments are (a) for slightly different subjects (e.g. the equivalent of English Language subject in KS1 National Curriculum is the Literacy and Communication area of learning in the Foundation Phase) and (b) the outcomes of these assessments are different (e.g. in the KS1 National Curriculum children are assessed against three levels, but in the Foundation Phase children are assessed against six levels).

5. Clearly, we are not able to control for everything, but the MCS does provide a better tool for taking into account other factors that can be associated with the outcomes than using existing educational administrative data alone.

6. These 15 children were amongst 188 MCS children who changed school between MCS3 and MCS4. For the purpose of this analysis we distinguish between those who attended a Foundation Phase pilot school in both MCS3 and MCS4, those children who attended a pilot school in either the MCS3 or MCS4, and those children who never attended a pilot school.

7. There are approximately 1348 infant/primary schools in Wales. Foundation Phase pilot schools constituted c. $1.6 \%$ of all schools. In the MCS, there are 606 schools represented in total and 11 Foundation Phase pilot schools (c.1.8\% of MCS schools).

8. Word Reading Ability scores were only available to those children who undertook the assessments in English. In Wales, 151 of the children completed a specially designed reading assessment in Welsh. However, their assessment scores cannot be used alongside the results from the English assessments, as they have still to be validated. It should be noted, therefore, that in the analyses of Word Reading Ability scores a small number of the MCS cohort of children in Wales are omitted. However, we are satisfied that this does not significantly skew the results (see Appendix 1).

9. So based on the whole MCS UK sample, all measures have a mean $=50$ and standard deviation $=10$. Age-adjusted scores (allowing for the spread in precise age at interview) are provided in the MCS data.

10. It is important to note that the teacher survey in MCS3 cannot be used in this analysis, since the Welsh Government asked that the teachers of children in Foundation Phase pilot schools would not be asked to participate in the teacher survey to avoid over-burdening teachers engaged in piloting the Foundation Phase programme.

11. It is important to note that the 'attitudes to learning' measure was not normally distributed - the resulting scores for this measure of well-being are positively skewed.

12. These school-level factors have been linked to the MCS from aggregated PLASC data in Wales by the Centre for Longitudinal Studies. School quintiles are based on all primary schools in Wales in 2005. 
13. This includes approximately 80 children who have left Wales since 2001-2002 and excludes 50 children who have since moved from England to Wales (one of whom attended a Foundation Phase pilot school at age five and seven). The analysis has been repeated based on the subpopulation of children in Wales at MCS4 (which includes inmigrants but excludes out-migrants), and the results are comparable. In line with using SPSS Complex Samples Plans, the whole MCS cohort was present when undertaking the analysis.

14. Age equivalences (in months) for gaps in Word Reading Ability scores can be found in Hansen 2010b. However, these must be treated cautiously as they can only be 'rough estimates' (58). Their real merit is in comparing the relative influence of different covariates on the dependent outcome.

\section{Notes on contributors}

Chris Taylor is a professor of education policy in the School of Social Science at Cardiff University and co-director of the Wales Institute for Social \& Economic Research, Data \& Methods (WISERD). He has been researching the geography of education for many years, particularly in relation to school admissions, education and neighbourhoods, education markets and participation in higher education. He was recently awarded an ESRC Mid-Career Fellowship to develop skills in the spatial analysis of the Millennium Cohort Study. He currently leads the official three-year independent evaluation of the Foundation Phase in Wales, the early years' flagship policy of the Welsh Government.

Heather Joshi is emeritus professor at the Centre for Longitudinal Studies, Institute of Education, University of London. She was previously the Director of the Centre for Longitudinal Studies from 2003 to 2010 and Director of the UK Millennium Cohort Study from 2000 to 2011. She is an economic demographer whose main research interests have been the family, the labour market, gender, child development and spatial issues. She is a Fellow of the British Academy and was awarded an OBE in 2002 for services to Women's Studies.

Caroline Wright is a postdoctoral research associate at the Wales Institute for Social \& Economic Research, Data \& Methods (WISERD) in Cardiff University. Her research interests include educational participation, geographies of education, neighbourhood effects, school effects and widening access to higher education. She is currently conducting research on the impact and effectiveness of widening access to higher education in Wales for the Higher Education Funding Council for Wales (HEFCW) and funded by the ESRC.

\section{References}

Bell, A. J. D., and K. Jones. 2013. "Explaining Fixed Effects: Random Effects Modelling of Time-series Cross-sectional and Panel Data." The Society for Political Methodology. Working Paper. http://polmeth.wustl.edu/mediaDetail.php?docId=1324.

Blewett, J., J. Tunstill, S. Hussein, J. Manthorpe, and S. Cowley. 2011. Children's Centres in 2011: Improving Outcomes for the Children Who Use Action for Children Children's Centres. London: King's College London.

Bukodi, E., and J. Goldthorpe. 2013. 'Decomposing 'Social Origins': The Effects of Parents' Class, Status, and Education on the Educational Attainment of Their Children." European Sociological Review 29 (5): 1024-1039.

Cunha, F., J. Heckman, L. Lochner, and D. Masterov. 2006. "Interpreting the Evidence on Life Cycle Skill Formation." In Handbook of the Economics of Education, edited by E. Hanushek and F. Welch, 698-809. Amsterdam: North Holland.

Davies, R., C. Taylor, T. Maynard, M. Rhys, S. Waldron, and D. Blackaby. 2013. Evaluating the Foundation Phase: The Outcomes of Foundation Phase Pupils (Report 1), Social Research No. 47/201. Cardiff: Welsh Government.

De la Rochebrochard, E. 2012. Millennium Cohort Study Data Note 1: The Home Learning Environment as Measured at Age 3. Centre for Longitudinal Studies, Institute of Education, University of London. 
Dearden, L., L. Sibieta, and K. Sylva. 2011. "The Socio-economic Gradient in Early Child Outcomes: Evidence from the Millennium Cohort Study." Longitudinal and Life Course Studies 2 (1): 19-40.

Ermisch, J. 2008. "Origins of Social Immobility and Inequality: Parenting and Early Child Development." National Institute Economic Review 205 (1): 62-71.

Feinstein, L. 2003. "Inequality in the Early Cognitive Development of British Children in the 1970 Cohort." Economica 70 (277): 73-97.

Field, F. 2010. The Foundation Years: Preventing Poor Children Becoming Poor Adults. London: HM Government Cabinet Office.

George, A., L. Stokes, and D. Wilkinson. 2012. "Does Early Education Influence Key Stage 1 Attainment? Evidence for England from the Millennium Cohort Study." National Institute Economic Review 222 (1): R67-R80.

Goldstein, H. 2011. Multilevel Statistical Models. 4th ed. Chichester: Wiley.

Hansen, K. 2010a. "Teacher Assessments in the First Year of School." In Children of the 21st Century (Volume 2): The First Five Years, edited by K. Hansen, H. Joshi, and S. Dex, 201-216. Bristol: The Policy Press.

Hansen, K., ed. 2010b. Millennium Cohort Study First, Second. Third and Fourth Surveys. London: Centre for Longitudinal Studies, Institute of Education, University of London.

Hansen, K., and D. Hawkes. 2009. "Early Childcare and Child Development." Journal of Social Policy 38 (2): 211-239.

Hopkin, R., L. Stokes, and D. Wilkinson. 2009. "Using Foundation Stage Profile Assessments to Assess Outcomes from Early Years Education." National Institute Economic Review 207: 102-112.

Jerrim, J., and A. Vignoles. 2013. "Social Mobility, Regression to the Mean and the Cognitive Development of High Ability Children from Disadvantaged Homes." Journal of the Royal Statistical Society: Series a (Statistics in Society) 176 (4): 887-906.

Jones, E., and S. Ketende. 2010. Millennium Cohort Study: User Guide to Analysing MCS Data Using SPSS. London: Centre for Longitudinal Studies, Institute of Education, University of London.

Joshi, H., S. Ketende, and S. Parsons. 2011. Child Development at Age Seven in Wales: Analysis of the Millennium Cohort Study, Number 25/2011. Cardiff: Welsh Government Social Research.

Ketende, S., H. Joshi, and R. Michael. 2010. "Income and Poverty." In Millennium Cohort Study Fourth Survey: A User's Guide to Initial Findings, edited by K. Hansen, E. Jones, H. Joshi, and D. Budge, 234-258. London: Centre for Longitudinal Studies.

Kiernan, K., and F. K. Mensah. 2011. "Poverty, Family Resources and Children's Early Educational Attainment: The Mediating Role of Parenting." British Educational Research Journal 37 (2): 317-336.

Maynard, T., C. Taylor, S. Waldron, M. Rhys, R. Smith, S. Power, and J. Clement. 2013. Evaluating the Foundation Phase: Policy Logic Model and Programme Theory, Social Research No. 37/2012. Cardiff: Welsh Government.

Melhuish, E., J. Belsky, A. Leyland, and J. Barnes. 2008. "Effects of Fully-established Sure Start Local Programmes on 3-year-old Children and Their Families Living in England: A Quasi-experimental Observational Study." The Lancet 372 (9650): 1641-1647.

Melhuish, E., J. Belsky, K. MacPherson, and A. Cullis. 2010. The Quality of Group Childcare Settings Used by 3-4 Year Old Children in Sure Start Local Programme Areas and the Relationship with Child Outcomes, Research Report DFE-RR068. London: Department for Education.

NAfW. 2003. The Learning Country: Foundation Phase - 3 to 7 Years. Cardiff: National Assembly for Wales.

Plewis, I., ed. 2007. The Millennium Cohort Study: Technical Report on Sampling. 4th ed. London: Centre for Longitudinal Studies, Institute of Education, University of London.

Raffe, D., K. Brannen, L. Croxford, and C. Martin. 1999. "Comparing England, Scotland, Wales and Northern Ireland: The Case for 'Home Internationals' in Comparative Research." Comparative Education 35 (1): 9-25.

Siraj-Blatchford, I., E. Milton, K. Sylva, J. Laugharne, and F. Charles. 2007. "Developing the Foundation Phase for 3-7-Year-Olds in Wales." The University of Wales Journal of Education 14 (1): 43-68. 
Sylva, K., E. Melhuish, P. Sammons, I. Siraj-Blatchford, and B. Taggart. 2004. The Effective Provision of Pre-school Education (EPPE) Project: Findings from the Pre-school to the End of Key Stage 1. London: DfES.

Taylor, C., T. Maynard, R. Davies, S. Waldron, M. Rhys, S. Power, L. Moore, D. Blackaby, and I. Plewis. 2013. Evaluating the Foundation Phase: Annual Report 2011/12, Social Research No. 43/2012. Cardiff: Welsh Government.

Taylor, C., G. Rees, and R. Davies. 2013. "Devolution and Geographies of Education: The Use of the Millennium Cohort Study for 'Home International' Comparisons across the UK." Comparative Education 49 (3): 290-316. doi:10.1080/03050068.2013.802927.

The Scottish Government. 2008. The Early Years Framework. Edinburgh: The Scottish Government.

University of London, Institute of Education, Centre for Longitudinal Studies. 2012a. Millennium Cohort Study: First Survey, 2001-2003. 10th ed. Colchester: UK Data Archive, August 2012. SN: 4683.

University of London, Institute of Education, Centre for Longitudinal Studies. 2012b. Millennium Cohort Study: Second Survey, 2003-2005. 7th ed. Colchester: UK Data Archive, August 2012. SN: 5350.

University of London. Institute of Education. Centre for Longitudinal Studies. 2012c. Millennium Cohort Study: Third Survey, 2006. 5th ed. Colchester: UK Data Archive, August 2012. SN: 5795.

University of London. Institute of Education. Centre for Longitudinal Studies. 2012d. Millennium Cohort Study: Fourth Survey, 2008. 3rd ed. Colchester: UK Data Archive [distributor], August 2012. SN: 6411, http://dx.doi.org/10.5255/UKDA-SN-6411-2.

Wincott, D. 2005. "Reshaping Public Space? Devolution and Policy Change in British Early Childhood Education and Care." Regional and Federal Studies 15: 453-470.

Wincott, D. 2006. "Devolution and the Welfare State: Lessons from Early Childhood Education and Care Policy in Wales." Environment and Planning C: Government and Policy 24: 279-295. 
Appendix 1. Academic assessments for children in Wales by language of completion

\begin{tabular}{|c|c|c|c|}
\hline \multirow[b]{2}{*}{ Academic assessments } & & \multicolumn{2}{|c|}{$\begin{array}{l}\text { Language used to } \\
\text { complete MCS4 Word } \\
\text { Reading Ability } \\
\text { assessment }\end{array}$} \\
\hline & & Welsh & English \\
\hline \multirow[t]{3}{*}{ MCS2 BAS Naming Vocabulary } & $\mathrm{N}$ & 137 & 1576 \\
\hline & Mean & 50.2 & 50.3 \\
\hline & St Dev & 9.9 & 10.2 \\
\hline \multirow[t]{3}{*}{ MCS2 Bracken School Readiness } & $\mathrm{N}$ & 130 & 1534 \\
\hline & Mean & 104.0 & 104.6 \\
\hline & St Dev & 14.2 & 15.5 \\
\hline \multirow[t]{3}{*}{ MCS4 Word Reading Ability } & $\mathrm{N}$ & & 1729 \\
\hline & Mean & & 47.4 \\
\hline & St Dev & & 10.7 \\
\hline \multirow[t]{3}{*}{ MCS4 Maths Ability } & $\mathrm{N}$ & 147 & 1743 \\
\hline & Mean & 46.8 & 50.3 \\
\hline & St Dev & 9.7 & 9.9 \\
\hline
\end{tabular}

